\title{
Toward a New Media Study in China: History and Approach
}

\section{Hailong Liu}

Remnin University, liuhailong@ruc.edu.cn

\section{Yidan Qin (iD)}

Remnin University, qydlly@ruc.edu.cn

IN HIS ETHNOGRAPHY of film production and cinema-going practices in Nigeria, Brian Larkin posed an interesting question: What would media theory have looked like if it had originated in Nigeria, rather than in Europe and the United States? ${ }^{1}$ This question may elicit insightful answers worldwide, as it invites us to adopt a "deWesternized" perspective of communication and media theories. The present essay considers similar problematics to Larkin: What difference would it have made if communication studies had been born in China? Answering this question helps us rethink the history and particularity of the field in China.

It is not necessary to emphasize the particularity of Chinese communication studies because the established discipline in China borrowed a great deal from U.S. communication research, or more precisely, from U.S. mass communication research. Their similarities are evident. As a result of historical outcomes dating back to the 1980 os, they share remarkably similar textbooks, educational vocabularies, and academic discourses. Moreover, the state-driven goal of building world-class universities and the always-present requirement of international publicity and visibility in recent years have further strengthened the processes of "Americanization" in the discipline of communication in China. The number of manuscripts from China in English-language communication journals is soaring, and the younger generation of Chinese communication researchers with backgrounds in U.S. education keeps increasing.
Hailong Liu and Yidan Qin, "Toward a New Media Study in China: History and Approach," History of Media Studies 1 (2021), https://doi.org/ 10.32376/d895aoea.e7da2342.

(c) (i) (5)

\footnotetext{
${ }^{1}$ Brian Larkin, Signal and Noise: Media, Infrastructure, and Urban Culture in Nigeria (Durham, NC: Duke University Press, 2008), 253.
} 
Chinese communication studies, however, differs from its analogues in the United States by dint of its own social cultural heritage and its fusion of Western academic resources. This essay focuses on three distinct characteristics of Chinese communication studies: (1) the role played by the state in academia; (2) the tradition of Chinese practical rationality; and (3) a new trend led by the reconceptualization of media in recent years. Although the first two characteristics can also be found in U.S. communication studies, they take on a new significance in the Chinese case. The final characteristic-the reconceptualization of media-provides a more striking contrast and may give us a significant demonstration of meaningful divergence from the U.S. model.

\section{The Presence of the State}

Much as Jefferson Pooley's "new history of mass communication" narration cast a light on the role of the state in U.S. communication studies, ${ }^{2}$ the state also played a determining role in the founding and diffusion of the communication discipline in China. One of the definitive moments in the solidification of Chinese communication studies was Wilbur Schramm's visit to China in 1982, sponsored by the Department of Education of Guangdong Province in China for distance-education training. ${ }^{3}$ At the time, Schramm was not just a scholar of communication but also a modernization theorist deeply involved in the United States' Cold War strategy. ${ }^{4}$ For modernization theorists like him, the "mission of the empire" meant using media to help developing countries achieve modernization. 5 The primary purpose of this modernization, based on U.S. and Western European models, was to curb the spread of communism. ${ }^{6}$

Chinese officials, however, found in the American tradition of mass communication study a tool they could employ in pursuit of the goal of the so-called Four Modernizations: the modernization of agriculture, industry, national defense, and science and technology.7 Therefore, although the aim of the two countries' modernization efforts differed, their similar usage of modernization discourses based on their own political purposes led them to reach a consensus. ${ }^{8}$

This kind of modernization consensus proved highly superficial. ${ }^{9}$ Focusing mainly on the technical aspect of economic growth, the consensus set aside the striking ideological differences between the two countries. The arrival of any kind of political crisis would soon render it fragile and influence the discipline's development. After the initial stirrings of modern academic communication study in China in the 1980s, communication studies has indeed experienced several ups and downs due to external factors. These ups and downs demonstrated the significant role played by the state.

History of Media Studies, vol. 1, 2021
${ }^{2}$ Jefferson Pooley, "The New History of Mass Communication Research," in The History of Media and Communication Research: Contested Memories, ed. David W. Park and Jefferson Pooley (New York: Peter Lang, 2008).

${ }^{3}$ Yelu Yu, "The Ice-Breaking Travel of the Science of Communication and 'Chinese Communication' in China (1982-2002)," in The Thirty Years of Chinese Communication Study, ed. Yihong Wang and Yiqing Hu (Beijing: Encyclopedia of China Publishing House, 2010), 611-12.

${ }^{4}$ Hailong Liu, "Wilbur Schramm and Communication Study in China: Cultural Cold War and Modernization Consensus," Journalism \& Communication 27, no. 6 (2020).

${ }^{5}$ Liu, "Wilbur Schramm and Communication Study," 102.

${ }^{6}$ M. E. Latham, Modernization as Ideology: American Social Science and "Nation Building" in the Kennedy Era (Chapel Hill: University of North Carolina Press, 2000), 53-56.

${ }^{7} \mathrm{Liu}$, "Wilbur Schramm and Communication Study in China," 103-4.

${ }^{8}$ Liu, "Wilbur Schramm and Communication Study in China," 103-4.

${ }^{9}$ Liu, "Wilbur Schramm and Communication Study in China," 105. 
First, after the Tiananmen Square incident in 1989, Chinese officials criticized communication studies as bourgeois liberalization in the field of journalism, suspending all related academic activities. Second, at the beginning of the twenty-first century, China made significant advancements in the areas of reform and opening up. Under these circumstances, Chinese communication study became effectively depoliticized, turning into a management tool instead. Research fields such as public relations and online public opinion studies quickly became popular at this time, gaining full official support. Third, since the political and trade disputes between China and the United States in 2018, some Chinese officials have suggested that American ideology hidden in social sciences such as communication studies might endanger unity among the Chinese people.

\section{Chinese Practical Rationality}

The second defining characteristic of Chinese communication studies we address here is its practical rationality. This tradition of practical rationality has a long history in Chinese philosophy. It shapes communication studies in two ways.

First, this tradition of thinking emphasizes ethical thoughts and practical values, and it exerts great influence on Chinese academia. Without exception, Chinese communication study is practice oriented. When communication studies entered China, early researchers attached more importance to its practical parts (such as audience research) than to theoretical construction. This orientation continues today. Many Chinese researchers have busied themselves with practical research topics such as online public opinion monitoring and analysis, the convergence of old and new media, the construction and communication of the national image of China, and international communication. These topics are indisputably important and can of course be found in many other countries, including the United States. But in China, this type of research has proved dominant. Often, governmental policies guide the questions asked and the methods of problematization.

Second, the tradition of Chinese practical rationality downplays abstract and logical reasoning. As some researchers have observed, compared to Western science, Chinese traditional science does not rely on experiments and the language of mathematical logic to construct theory. ${ }^{10}$ Intuition and imagination have guided its understanding of the world, ${ }^{11}$ and it therefore takes the form of insightful but always unfalsifiable observations and explanations rather than verifiable theoretical propositions. Communication research, especially during the early stage of communication study in China, was
${ }^{10}$ Georgette Wang, Vincent Shen, and Ven-hwei Lo, "Chinese Communication Theory Construction: Mission Impossible?" Mass Communication Research, no. 70 (2002): 7 .

${ }^{11}$ Wang, Shen, and Lo, "Chinese Communication Theory Construction." 
full of personal observations and short on rigorous methods. Embedded in this background, some communication scholars emphasized that Chinese researchers first needed to transform and operationalize their traditional ideas and ordinary concepts before entering into a dialogue with Western academics. ${ }^{12}$

\section{The Current Trend toward a New Media Study}

The third characteristic of Chinese communication study is its socalled media turn. Generally, the dominant paradigm in communication research established after World War II focuses principally on mass media and has an obvious agenda bias of effects research based on media content. In this way, media are often considered objective tools for the transmission of information. For example, Schramm defined media as "machines interposed in the communication process to multiply and extend the delivery of information."13 Marshall McLuhan gave a new direction, totally different from Schramm's. He showcased an insightful definition of the medium: "the medium is the message" (emphasizing the form rather than the content of the medium) and the "extension of man" (the embodiment interpretation of the medium) ${ }^{14}$ After McLuhan, and partly through his influence, we have seen the development of numerous media theories. Instead of regarding media as carriers of messages, these media theories highlight media's constitutive roles in human existence, an idea that largely drives traditional communication scholarship. As an outcome of this influence, communication study has begun to reconceptualize its key concepts (such as media and communication), informing the so-called media turn.

Chinese scholars have demonstrated their insights and creativity during this new turn. To some extent, this results from the specific circumstances in China. In recent years, digital media and the related infrastructure construction projects are developing rapidly in the country. The speed of progress surpasses that in many developed countries. In part, this is the result of full governmental supportthe digital media industry is one of the most important fields for Chinese economic development, so it benefits from a great deal of governmental support. This embrace of digital media can also be traced to Chinese people's optimistic attitude toward new technology, an attitude deeply rooted in ideas of social evolutionism and social revolution introduced to China from the West in the late nineteenth century. Since then, the Chinese philosophy of history has changed almost completely from one of degeneration or a cyclical theory of history to a progressive and revolutionary one. Influenced by these ideas, Chinese people tend to consider new media more progressive than old media.

History of Media Studies, vol. 1, 2021

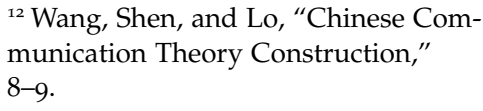
munication Theory Construction," $8-9$.

${ }^{13}$ Wilbur Schramm and William Earl Porter, Men, Women, Message, and Media: Understanding Human Communication (New York: Harper \& Row, 1973), 132.

${ }^{14}$ Marshall McLuhan, Understanding Media: The Extensions of Man, 2nd ed. (New York: New American Library, 1964), viii. 
In the context of the flourishing market for digital media, Chinese scholars developed their special attention to forms of media and their relation to human beings. They are involved in this media turn in two ways: general theoretical reflection and further empirical research embedded in local experiences. These efforts largely exemplify Chinese scholar Huang Dan's appeal. He once proposed that, to correct the overwhelming research bias of mass media content and effects, medium itself should serve as the fundamental perspective of communication study. ${ }^{15}$ By employing a broader conceptualization of media, he suggested, we would be better prepared to grasp the essence of communication study and therefore better organize the whole field. ${ }^{16}$

Such appeal is noticeably increasing. Many Chinese researchers like Huang Dan have begun to extend the traditional understanding of media. Alongside "representative media" such as radio, film, and television, they pay attention to "unrepresentative media" such as roads, cities, bodies, technologies, infrastructure, and viruses. These scholars have done much to investigate previously undervalued topics. For example, some researchers have begun to focus on the "new type of tie" between city and communication, forming a community of urban communication studies, based at Fudan University, to respond to the varied new media practices and urbanization of Chinese society from the perspective of media. ${ }^{17}$ Some researchers focused their attention on the body and its relation to communication. They have used the concept of embodiment to reconsider the role of the body in the process of communication, reflecting on varied embodied practices under the conditions of new media. ${ }^{18}$ Additionally, we have witnessed the blossoming of subfields, including media materiality studies, ${ }^{19}$ media archaeology, ${ }^{20}$ media geography, ${ }^{21}$ and media anthropology. ${ }^{22}$ Evidently, the new media turn is neither a replacement of nor a supplement to existing communication studies. It is its own mode of thought that invites us to re-consider communication as a whole.

\section{Conclusion}

Let us go back to the questions we raised at the beginning of this essay. Our tentative answer would be that, if communication studies had originated in China, the striking political and cultural disparities would make it different from American communication studies. First, the discipline would be more practically oriented and would need to meet the need of political and commercial propaganda. Second, Chinese scholars may develop philosophical ways of considering media and communication in the style of scholars from France, Ger-

History of Media Studies, vol. 1, 2021

\author{
${ }^{15}$ Dan Huang, "Preface to Meijie \\ Daoshuo Translation Series," in Vir- \\ ilio and the Media, ed. John Armitage \\ (Beijing: Communication University of \\ China Press, 2019), 13. \\ ${ }^{16}$ Huang, "Preface to Meijie Daoshuo \\ Translation Series," 13.
}

${ }^{17}$ For research on this topic, see Dan Huang, Preface to Urban Communication: On the History and Reality of the Chinse City, ed. Dan Huang (Shanghai: Shanghai Jiaotong University Press, 2015), 1-7; Wei Sun, "Research Approaches to and Theoretical Innovation for Urban Communication," Modern Communication 40, no. 12 (2018): 29-40.

${ }^{18}$ For research on this topic, see Hailong Liu, "Body Agenda and the Future of Communication Studies," Journal of Journalism \& Communication 40, no. 2 (2018): 37-46; Hailong Liu and Kairong Shu, "Embodiment and Body Idea in Communication Studies: A Perspective of Phenomenology of Perception and Cognitive Science," Journal of Lanzhou University (Social Sciences) 47, no. 2 (2019): 8o-89; Hailong Liu, Zhuoxiao Xie, and Kairong Shu, "Networked Bodies: Human as Viruses and Patches in Technological Systems," Journalism Research, no.5 (2021): 40-55, 122-23; Bifeng Rui and Zhen Ang, "Embodied Communication: From the Perspective of Cognitive Linguistics," Modern Communication 43, no. 4 (2021): 3339; Zhuoxiao Xie, "Bodies as Mobile Media: The Embodied Communication Practices and Communicator's Bodies in the Cross-Border Shopping," Chinese Journal of Journalism \& Communication 43 , no. 3 (2021): 40-57. 
many, or Japan, rather than conducting communication research with quantitative methods.

As mentioned above, globalization, an increasing amount of academic exchange, and especially state-encouraged international publication have greatly reduced the differences between Chinese and American communication studies. One characteristic of Chinese communication study lining up with its American analogues is that it has also held a relatively narrow view of media and communication in the past few decades. Audience research and effects research long dominated the research agenda. However, this traditional perspective gradually lost its theoretical competitiveness for today's digital society.

The media turn discussed above has brought opportunities for Chinese scholars to transcend the original American communication establishment and develop a new kind of media study. During this process, European media studies and philosophical currents such as German media theory, mediatization theory, and mediology were reappraised for their possible value to understand the current situation here in China. Some years ago, John Peters said, "Please do not think me extravagant if I say that we North American media scholars risk the fate of Casaubon without grappling with recent German work. We need not swallow it whole, but grapple we must."23 Today, Chinese scholars, like scholars from elsewhere around the globe, are doing just this kind of grappling. Compared with the situation in the 1980 s, this time we are witnessing more theoretical reflection in Chinese academia, instead of simple learning and imitation. A new kind of media study embedded in Chinese experiences is worth the wait.

\section{Bibliography}

Guo, Jianbin. "Media Anthropology: A Research Based on Literatures." In Media World and Media Anthropology, edited by Qiyao Deng, 17-45. Guangzhou: Sun Yat-Sen University Press, 2015.

Huang, Dan. "Preface to Meijie Daoshuo Translation Series." In Virilio and the Media, edited by John Armitage, 1-14. Beijing: Communication University of China Press, 2019.

- Preface to Urban Communication: On the History and Reality of the Chinse City, edited by Dan Huang, 1-7. Shanghai: Shanghai Jiaotong University Press, 2015.

Larkin, Brian. Signal and Noise: Media, Infrastructure, and Urban Culture in Nigeria. Durham, NC: Duke University Press, 2008.

Latham, M. E. Modernization as Ideology: American Social Science and "Nation Building" in the Kennedy Era. Chapel Hill: University of North Carolina Press, 2000.
19 For research on this topic, see Gehao Zhang and Lei Zhang, "A Dialectic Thinking between Material Being and Anthropogenic Seeing: The Materiality Turn in Media and Cultural Analysis," Global Journal of Media Studies 6, no. 2 (2019): 103-15; Guohua Zeng, "Media and Communication Materiality Studies: Theoretical Origins, Research Approaches and Subareas," Chinese Journal of Journalism \& Communication 42, no. 11 (2020): 6-24.

${ }^{20}$ For research on this topic, see Hongzhe Wang, "Eye of the Sky and the Deep: Media Archeology of Crittercam," Film Art, no. 3 (2018): 23-26; Chang Shi, "Yesterday Once More: The Rise of Media Archaeology and Its Awareness of Problems," Journalism \& Communication 26, no. 7 (2019): 33-53, 126-27; Ji Pan and Lingyan Li. "Media Research, Technological Innovation and Knowledge Production: Insights from Media Archeology-Conversation with Professor Siegfried Zielinski," Chinese Journal of Journalism \& Communication 42, no. 7 (2020): 96-113.

${ }^{21}$ For research on this topic, see Jianbin Guo, "Media Anthropology: A Research Based on Literatures," in Media World and Media Anthropology, ed. Qiyao Deng (Guangzhou: Sun Yat-Sen University Press, 2015), 17-45; Xinru Sun, "Media Anthropology as a 'Cultural Method,'" Nanjing Journal of Social Sciences, no. 5 (2019): 113-20, 156; Xinru Sun and Hong Duan, "Rethinking 'Embeddedness': Relational Dimension of Media Anthropology," Nanjing Journal of Social Sciences, no. 9 (2020): 103-11.

${ }^{22}$ For research on this topic, see Yan Yuan, "When Geographers Talk about Media and Communication, What Do They Talk About? Comments on Paul Adams' Geographies of Media and Communication," Chinese Journal of Journalism \& Communication 41, no. 7 (2019): 157-76; Yan Yuan, “The Materiality of Television and the Politics of Mobility: A Media Geographic Study from Two Urban Villages," Journalism $\mathcal{E}$ Communication 23, no. 6 (2016): 92-104, 128.

${ }^{23}$ John Durham Peters, "Strange Sympathies: Horizons of Media Theory in America and Germany," Electronic Book Review, June 4, 2009. 
Liu, Hailong. "Body Agenda and the Future of Communication Studies." Chinese Journal of Journalism \& Communication 40, no. 2 (2018): 37-46. https://doi.org/10.13495/j. cnki.cjjc. 2018. 02.006.

Liu, Hailong. "Communication of Virus." The Thinker, no. 29 (2020):15.

Liu, Hailong. "Wilbur Schramm and Communication Study in China: Cultural Cold War and Modernization Consensus." Journalism E Communication 27, no. 6 (2020): 92-109, 128.

Liu, Hailong, and Kairong Shu. "Embodiment and Body Idea in Communication Studies: A Perspective of Phenomenology of Perception and Cognitive Science." Journal of Lanzhou University (Social Sciences) 47, no. 2 (2019): 8o-89. https://doi.org/10. 13885/j . issn. 1000-2804.2019.02.010.

Liu, Hailong, Zhuoxiao Xie, and Kairong Shu. "Networked Bodies: Human as Viruses and Patches in Technological Systems." Journalism Research, no.5 (2021): 40-55, 122-23.

McLuhan, Marshall. Understanding Media: The Extensions of Man. 2nd ed. New York: New American Library, 1964.

Pan, Ji and Lingyan Li. "Media Research, Technological Innovation and Knowledge Production: Insights from Media ArcheologyConversation with Professor Siegfried Zielinski." Chinese Journal of Journalism \& Communication 42, no. 7 (2020): 96-113. https: //doi.org/10.13495/j.cnki.cjjc.2020.07.005.

Peters, John Durham. "Strange Sympathies: Horizons of Media Theory in America and Germany." Electronic Book Review, June 4, 2009. http:/ / electronicbookreview.com/essay/strange-sympathieshorizons-of-media-theory-in-america-and-germany/.

Pooley, Jefferson. "The New History of Mass Communication Research." In The History of Media and Communication Research: Contested Memories, edited by David W. Park and Jefferson Pooley, 43-70. New York: Peter Lang, 2008.

Rui, Bifeng, and Zhen Ang. "Embodied Communication: From the Perspective of Cognitive Linguistics." Modern Communication 43, no. 4 (2021): 33-39. https://doi.org/10.3969/j.issn. $1007-8770.2021 .04 .007$.

Schramm, Wilbur, and William Earl Porter. Men, Women, Message, and Media: Understanding Human Communication. New York: Harper \& Row, 1973 .

Shi, Chang. "Yesterday Once More: The Rise of Media Archaeology and Its Awareness of Problems." Journalism \& Communication 26, no. 7 (2019): 33-53, 126-27.

Sun, Wei. "Research Approaches to and Theoretical Innovation for Urban Communication." Modern Communication 40, no. 12 (2018): 
29-40. https://doi.org/10.3969/j . issn. 1007-8770.2018. 12.

006.

Sun, Xinru. "Media Anthropology as a 'Cultural Method.' " Nanjing Journal of Social Sciences, no. 5 (2019): 113-20, 156. https://doi. org/10.15937/j . cnki. issn1001-8263.2019.05.015.

Sun, Xinru, and Hong Duan. "Rethinking 'Embeddedness': Relational Dimension of Media Anthropology." Nanjing Journal of Social Sciences, no. 9 (2020): 103-11. https ://doi.org/10.15937/ j. cnki . issn1001-8263.2020.09.014.

Wang, Georgette, Vincent Shen, and Ven-hwei Lo. "Chinese Communication Theory Construction: Mission Impossible?" Mass Communication Research, no. 70 (2002): 1-15.

Wang, Hongzhe. "Eye of the Sky and the Deep: Media Archeology of Crittercam." Film Art, no. 3 (2018): 23-26.

Xie, Zhuoxiao. "Bodies as Mobile Media: The Embodied Communication Practices and Communicator's Bodies in the Cross-Border Shopping." Chinese Journal of Journalism E Communication 43, no. 3 (2021): 40-57. https://doi.org/10.13495/j.cnki.cjjc. 2021. 03.003.

$\mathrm{Yu}$, Yelu. "The Ice-Breaking Travel of the Science of Communication and 'Chinese Communication' in China (1982-2002)." In The Thirty Years of Chinese Communication Study, edited by Yihong Wang and Yiqing $\mathrm{Hu}$, 6o9-19. Beijing: Encyclopedia of China Publishing House, 2010.

Yuan, Yan. "The Materiality of Television and the Politics of Mobility: A Media Geographic Study from Two Urban Villages." Journalism $\mathcal{E}$ Communication 23, no. 6 (2016): 92-104, 128.

- "When Geographers Talk about Media and Communication, What Do They Talk About? Comments on Paul Adams' Geographies of Media and Communication." Chinese Journal of Journalism $\mathcal{E}$ Communication 41, no. 7 (2019): 157-76. https: //doi.org/10.13495/j.cnki.cjjc. 2019.07.011.

Zhang, Gehao, and Lei Zhang. "A Dialectic Thinking between Material Being and Anthropogenic Seeing: The Materiality Turn in Media and Cultural Analysis." Global Journal of Media Studies 6, no. 2 (2019): 103-15. https ://doi.org/10.16602/j.gmj . 20190018.

Zeng, Guohua. "Media and Communication Materiality Studies: Theoretical Origins, Research Approaches and Subareas." Chinese Journal of Journalism $\mathcal{E}$ Communication 42, no. 11 (2020): 6-24. https://doi.org/10.13495/j.cnki.cjjc.2020.11.001. 